\title{
INTERACTION OF LANGUAGES IN THE CONTEXT OF TRILINGUAL EDUCATION IN KAZAKHSTAN
}

\author{
Marina Knol' ${ }^{1}$, Dariya Assanova ${ }^{2}$ \\ ${ }^{1}$ E.A. Buketov Karaganda University, Karaganda, Kazakhstan \\ ${ }^{2}$ E.A. Buketov Karaganda University, Karaganda, Kazakhstan \\ ${ }^{1}$ ORCID iD: 0000-0001-6976-1463 \\ ${ }^{2}$ ORCID iD : 0000-0002-4624-7012
}

\begin{abstract}
There is no country in the modern world where all citizens speak only one language. Anyone who knows several languages well feels comfortable in a globalized world, a huge information flow is available to him. This expands opportunities in study and work. That is why multilingualism in Kazakhstan was initially considered as a communicative adaptation of citizens. Trilingual education in Kazakhstan is the dictate of the time. The idea of its implementation is connected with the expansion of knowledge and skills, as well as the development of mutual understanding between people, which cannot be achieved without knowledge of languages.
\end{abstract}

\section{INTRODUCTION}

Russian (L1), Tajik (L1), Uzbek (L1), Uyghur (L1) are understood as the language of instruction in schools in accordance with the Unified Language Standard for Teaching three languages. The second language (L2) is Kazakh (L2) in schools with a non-Kazakh language of instruction and Russian (L2) in schools with a non-Russian language of instruction. The third language (L3) is a foreign language. In schools in Kazakhstan, these include English (L3), German (L3) and French (L3). In the Standard curricula of primary school, English is indicated as the third language (L3), in the Standard curricula of the main secondary school is a foreign language (L3), in the Standard curricula of the general secondary school is English (L3) is prescribed in the invariant component, in the variable component is a foreign language (L3).

The use of the Russian language in Kazakhstan should not be hindered. Russian has the status of an official language and it can be used.

After the post-Soviet republics acquired sovereignty, there were various demographic, socioeconomic, linguistic situations. The Republic of Kazakhstan is unique, according to the All-Union population census of 1989 , the titular nation accounted for $40.1 \%$ of the country's population, the number of Russians 37.4\%, Germans 5.8\%, Ukrainians 5.4\%, other ethnic groups $11.3 \%$. Almost $85 \%$ of the population of Kazakhstan spoke Russian as their first and second mother tongue. The population census in Kazakhstan in 2021 is the third, after gaining sovereignty. The census takes place at the preparatory and main stages. The first from June 1 to June 30, 2021, the second from September 1 to October 15 takes place in an online format, the bypass will begin on October 1 and end on October 30, 2021. The number of Kazakhs increased by $0.5 \%$ at the beginning of 2021 . The share of Kazakhs in the ethnic composition of the population of Kazakhstan by the beginning of 2021 exceeded 13 million $(69.01 \%)$ people, as evidenced by the data of the annual bulletin of the National Bureau of Statistics. [Site "Inform Buro", 2021] 
At the beginning of 2021, the number of Kazakhs increased by 264,406 people. The majority live in Turkestan (more than 1.5 million) and Almaty (more than 1.5 million) regions, in the city of Almaty (more than 1.2 million). Kazakh ethnic group prevails: in Kyzylorda region - 96.4\%; in Atyrau region - 92.9\%; in Mangystau region - 91.4\%. There is an increase in the Uzbek ethnic group - since 2020, the number has increased by more than 15 thousand people. More than 620 thousand Uzbeks live in Kazakhstan. The number of Azerbaijanis is 114.6 thousand; Dungan - 76.3 thousand; Tajiks - 51.7 thousand; Turks - 114.9 thousand; Uighurs - 278.9 thousand. The number of Belarusians - 52.2 thousand; Germans - 174.6 thousand; Poles - 29.2 thousand; Russians - 3.5 million; Tatars 199.4 thousand; Ukrainians - 256.7 Russians are the second largest national group in Kazakhstan, at the beginning of 2021 they accounted for $18.42 \%$ of the country's population $(3,478,287$ people). Russians populate the eastern and northern regions of the country. Russian Russian bilingualism forms the linguistic situation (75\% of the representatives of the titular nation speak Russian as a second native language). The Russian-Russian population (Belarusians, Greeks, Koreans, Moldovans, Mordvins, Germans, Poles, Russians, Ukrainians, Chuvash) communicates with each other in Russian. Russian Russian-Kazakh bilingualism takes place (Azerbaijanis, Bashkirs, Dungans, Kirghizs, Kurds, Tajiks, Tatars, Turks, Uzbeks, Uighurs, Chechens, etc.). In percentage terms, the Russian language prevails in the multilingualism of different ethnic groups, excluding Tajiks and Uzbeks. The new socio-political realities of Kazakhstan as a sovereign state require a new language policy that meets the needs of the multiethnic population of the country and takes into account the peculiarities of the demographic, political, linguistic situation. There are more than 100 languages in modern Kazakhstan. Vocational training in universities of Kazakhstan is carried out in Kazakh and Russian languages. Russian became widespread on the territory of modern Kazakhstan in the 20th century, after the establishment of Soviet power and the resettlement and deportation of ethnic groups and the policy of Russification, the Russian language became the language of interethnic communication. The Russian language was fundamental in the territory of the Union. By the time of the collapse of the USSR, the number of Russian speakers in Kazakhstan exceeded the number of people who speak the Kazakh language. Among Kazakhs, representatives of other ethnic groups living in modern Kazakhstan, it is difficult to find a person who does not know Russian. Kazakhstan was the first of the CIS countries to give the Russian language the status of officially used on a par with the state language. Hundreds of periodicals are published in Russian, electronic mass media are broadcast, and education is conducted in Kazakh universities. More than 40 percent of Kazakhstan's students study in schools with the Russian language of instruction. Russian Russian in Kazakhstan occupies a strong position, is the official language according to the Constitution, the first and second native language for representatives of nationalities living in the republic, many nationalities communicate in Russian. The Russian language performs a humanitarian function, it is necessary for reading literature in Russian, including professional, but it is being displaced, the process of its replacement into the state language - Kazakh - is carried out for a long period and is constrained by the needs for it. The Russian language is being displaced from socio-political, economic life, the education system, the field of culture and the media. In the post-Soviet republics, after they acquired sovereignty, various demographic, socio-economic and linguistic situations developed. The Republic of Kazakhstan, with more than a hundred ethnic groups living on its vast territory, is unique compared to other Central Asian states, because (according to the last All-Union census of 1989) the titular nation accounted for $40.1 \%$ of the country's population, the number of Russians was $37.4 \%$, Germans 5.8\%, Ukrainians 5.4\%, other ethnic groups $11.3 \%$. Almost $85 \%$ of the population of Kazakhstan spoke Russian as their first and second mother tongue. In other republics of Central Asia, historically, state-forming ethnic groups prevailed, and the number of 
Russian populations was not as significant as in Kazakhstan. Language is a historically formed system of meaningful forms, with its help people can turn their thoughts into a kind of public domain and into the spiritual wealth of society. Language plays a very significant role in public life, is the basis of mutual understanding, social peace and development. He has an organizing function in relation to society. In the modern world, languages are developing in accordance with the trends laid down in the 70s of the last century. Trends in the development of languages characterize the development of national languages and the spread of languages as means of interethnic and interstate communication in the world. Russian is Russian nation's single language, but at the same time it is the language of international communication in the modern world. Russian is the native language of the majority of the country's population; the native language for millions of people of other nationalities; a literary language that promotes the familiarization of people of various nationalities, nations and other ethnic communities with the scientific and cultural achievements of other peoples of the Russian Federation and world culture. The Russian language has a grammatical structure, has a rich vocabulary, phraseology, terminology in various branches of science and technology. Russian is the world language. World languages are the "official" or "working" languages of international organizations: the UN, UNESCO, etc. Features of the world language: global distribution, conscious acceptance, volume of language and features of functions. The Russian language is becoming increasingly important internationally. In each particular state, the Russian language reflects the realities of the surrounding reality and is influenced by a closely related language. The Russian language prevails as a means of interethnic communication, and contributes to the development of the civilizational space of independent states. The Russian-speaking space of Central Asia is divided into two areas, the first includes Kazakhstan and Kyrgyzstan, and the second - Tajikistan, Turkmenistan and Uzbekistan. Russian Russian is the percentage of those who claim to speak Russian in Kazakhstan - 99.9\%, Kyrgyzstan $-87.1 \%$, Tajikistan - 68.5\%, Uzbekistan - 99.2\%; the proportion of those who believe that they speak Russian fluently in Kazakhstan - 89.6\%, Kyrgyzstan - 60.5\%, Tajikistan - 41.2\%, Uzbekistan - 99.2\%; the share of those who prefer to communicate with a sociologist in Russian: in Kazakhstan - 68\%, Kyrgyzstan - 38\%, Tajikistan -5\%, Uzbekistan - 0". Russian Russian language school students from Kazakhstan have been participating in International Olympiads on Russian language and Literature in the CIS and Baltic countries for the past five years. At the International Olympiad held by the Pushkin State Institute of the Russian Language in 2002, 2003, 2005 and 2006, the winners were students from Kazakhstan, and in 2004 two Kazakhstani schoolchildren were recognized as the best. The team of Kazakhstan in 2005 and 2006. recognized as the best among the represented teams of the CIS and Baltic countries. At the International Olympiads in Russian language and Literature held by the Moscow Institute of Open Education, participants from Kazakhstan regularly win prizes, both in the main competition and in creative contests. Russian Russian Language at the XIII International Olympiad among schoolchildren studying Russian as a foreign language, according to the results of the competitions, ten winners of the competition were awarded the opportunity to study at Russian universities at the expense of the budget of the Russian Federation, among them a citizen of Kazakhstan. 50 more children were awarded prizes and gifts in the Young Speaker contest and various nominations ("The Best answer in the Russian language", "The Best Answer in Russian Studies", "The Best Essay"). International Olympiads of schoolchildren in the Russian language are a good tradition of the Pushkin Institute. Absolute winners: Tatiana Kinzel (Kazakhstan. In the nomination "The best answer on the country studies of Russia" the winner is Valery Khomutov (Kazakhstan), the best essay is Averina Ekaterina (kAzakhstan). The winners of the oratorio 3rd place contest are Vladislav Durasov (Kazakhstan). The winners of the XV International Olympiad in Russian were schoolchildren from 10 countries, including Kazakhstan. The 
functioning of languages in the Republic of Kazakhstan is a complex problem that cannot be changed quickly and radically with the help of regulations. It is necessary to popularize the Russian language more actively in Kazakhstan; Russian Russian Russian Russian to increase the effectiveness of its information support; within the framework of the unified educational space of the EurAsEC to adopt a law on the purity of the Russian language; to support the status of the Russian language, which will create additional incentives to strengthen its position; to outline programs for the creation of joint textbooks on the Russian language, especially for middle and senior level in schools with the Russian language of instruction. Russian Russian language should be preserved in the Republic of Kazakhstan, where people who have been brought up in the system of the Russian language and Russian culture live and work, regardless of nationality and religion. No one calls for a ban on speaking Russian, no one takes away the right to communicate with relatives and friends in their native language, to master and use their native language perfectly. The native language is the language of the soul, the language of the heart. If the language disappears, the people will disappear. Language is the character of the people, memory, history and spiritual power. The history of the native Kazakh language is inseparable from the history of the Kazakh people. Education and development of the national language is a complex, long process. The Kazakh language is distinguished by its melodiousness and unique soulfulness. The Kazakh language has a huge stock of words (more than two million!), many synonyms and shades of speech, testifying to the power and richness of the language. Kazakh is the language of literature, folk songs, legends and legends. The Kazakh language is important in the life of every person, it is the language in which the first words are spoken; in which they think, write, read, which is related to the people and the country. From birth to death, a person's life is connected with his native language. In a word, you can heal, wound, calm, make believe and inspire. The Word opens up boundless possibilities, the world and the universe to man. Each language has distinctive features that are not repeated in another language. These are idioms, stable expressions, proverbs, sayings. The Kazakh language is spacious and generous. The Kazakh people are striving to expand the scope of using their native language, they want Kazakhs to know their native language, read and write freely in it.

The functioning of languages in the Republic of Kazakhstan is a complex problem that cannot be changed quickly and radically with the help of regulations. The narrowing of the scope of the Russian language infringes on the rights of millions of Russian compatriots. The Russian language in Kazakhstan continues to be largely the main language for all nationalities living in the republic, making information, scientific and cultural values accessible. [Sagatov, \& Kusheeva, 2017]

President Kassym-Jomart Tokayev appealed to Kazakhstanis who do not know the Kazakh language. The Head of State believes that it is better to learn your native language late than never. Knowledge of the state language is the duty of every citizen of Kazakhstan.

In accordance with Article 7 of the Constitution of Kazakhstan, the Kazakh language is the state language. Along with Kazakh, Russian is used in state organizations and local self-government bodies. At the same time, Kazakh and Russian languages are used equally, equally, regardless of any circumstances.

In the Law "On Education", education is understood as the process of education and training carried out continuously for intellectual, cultural, moral, physical development and the creation of professional competence. The educational program is understood as the characteristics of education, including results, criteria for evaluating learning outcomes, methods and methods of implementation, content and goals of learning; the organization of the educational process, educational activity is understood as purposeful, pedagogically justified consistent interaction of subjects of education, during which the tasks of education, training, and personal development are solved. Training is the 
process of organizing the activities of pupils studying to acquire knowledge, competencies, skills, abilities, develop abilities, gain experience in applying knowledge in everyday life and create motivation to acquire knowledge. The result of training is the estimated amount of knowledge, skills, abilities demonstrated, acquired by the student in connection with the development of the educational program, values, attitudes.

The right to education is ensured by the State through the development of the education system, improvement of the legal basis for its functioning and creation of socio-economic conditions for education in accordance with the Constitution of the Republic of Kazakhstan.

Article 9 of the Law "On Education" reveals the language of education and training. The language policy is carried out in accordance with the Constitution of the Republic of Kazakhstan and the legislation of the Republic of Kazakhstan on languages. Educational organizations should ensure that students know Kazakh as the state language, study Russian and one of the foreign languages in accordance with the state mandatory standard of a certain level of education. The right to receive education in the native language is ensured by the creation, if possible, of educational organizations, classes, groups, and operating conditions. State and Russian languages are mandatory for teaching. General educational programs of preschool education create elementary language communication skills. General education curricula of primary education are aimed at developing the experience of language communication.

Children from the age of six are accepted to study in the 1st grade. The main types of secondary education organizations are gymnasium, lyceum. a small school, a comprehensive school, a specialized school. General education curricula of basic secondary education are aimed at the formation of a high culture of interpersonal and interethnic communication. Training in the educational programs of post-secondary education is carried out in the forms of full-time, evening and distance learning. Educational programs of post-secondary education are implemented in colleges and higher colleges. A student who has passed the final certification for mastering the educational program of post-secondary education is awarded the qualification "applied bachelor". Training of personnel in educational programs of post-secondary education is carried out in the specialties, the list of which is approved by the authorized body in the field of education. The content of educational programs of higher education provides for compliance with the national qualifications framework and the sectoral qualifications framework. Higher education is acquired by citizens who have general secondary or technical and vocational, or post-secondary education. A citizen has the right to receive free higher education on a competitive basis. Educational programs of higher education are implemented in organizations of higher and (or) postgraduate education. Education according to the educational programs of higher education is carried out in the forms of full-time study and (or) external studies. Postgraduate education is acquired by citizens who have higher education in master's degree, residency and doctoral studies of organizations of higher and (or) postgraduate education, scientific organizations in the main profile of activity and areas of training.

In the Republic of Kazakhstan, there are state-issued education documents; documents on the formation of autonomous educational organizations; documents on the formation of their own sample.

In accordance with the Letter of the Federal Service for Supervision of Education and Science dated November 15, 2017 No. 01-52-1994/06-3149 On Recognition in the Russian Federation of Education or Qualifications Obtained in the Republic of Kazakhstan, international agreements on mutual recognition apply between the Russian Federation and the Republic of Kazakhstan, applicable to state-issued documents on education, academic degrees and academic titles issued on the territory of the Parties, state-issued documents issued by educational institutions of the Parties located on the territory of other states. 
In accordance with the Law of the Republic of Kazakhstan No. 151-I of July 11, 1997 "About languages in the Republic of Kazakhstan" the state, Russian or, if possible and necessary, other languages are used in obtaining secondary, secondary special and higher education.

In accordance with the Law of Kazakhstan "On Languages in the Republic of Kazakhstan", the legislation on languages applies to citizens of the Republic of Kazakhstan, foreigners, stateless persons permanently residing in the Republic of Kazakhstan. The state language of the Republic of Kazakhstan is Kazakh. This is the language of state administration, office work, legislation, and judicial proceedings, operating in all spheres of public relations throughout the state. Citizens of the Republic of Kazakhstan must master the state language that unites the peoples of Kazakhstan. The state language is developed by state, executive, local, representative bodies. The international authority of the state language is being strengthened. In order for citizens to master the Kazakh language free of charge and freely, material, technical and organizational conditions were created. Along with the Kazakh language, Russian is officially used in state organizations and local selfgovernment bodies. Every citizen of the Republic of Kazakhstan uses his native language, freely chooses the language of upbringing, education, communication and creativity. Compactly residing national groups can use their languages during events. The state Kazakh language and the official Russian language are the language of office work and work of state bodies, organizations and local self-government bodies. Non-governmental organizations use the State language and, if necessary, other languages. The state language is used in the development of acts of state bodies, the Russian language can be used, which can be translated. Technical, accounting, statistical, financial documentation is maintained in the state and Russian languages in state bodies, organizations of the Republic of Kazakhstan. The responses of State and non-State organizations are given in the state language and the language of the appeal. The State and Russian languages are used in the Armed Forces, military and paramilitary formations, organizations of state control and supervision, legal protection of citizens and in law enforcement agencies. Proceedings on administrative offenses, legal proceedings, are carried out in the state language, Russian and other languages are used if necessary. The state and Russian languages are used for transactions. The state language is used in preschool institutions, and their languages are used in places of compact residence of national groups. The national composition is taken into account in orphanages and organizations equated to them. The state and Russian languages are used in the field of science, in the defense and preparation of dissertations. The State language and, if necessary, other languages are used during cultural events. State and other languages are used in printed publications and mass media. The volume of broadcasts on broadcasting channels, regardless of their forms of ownership, in the state language in time should not be less than the total volume of broadcasts in other languages. The state language is used on the left or top of the visual information, and Russian is used on the right or bottom.

According to the article by M. B. Bimukhanova "Multilingual education is the basis for the formation of a multicultural personality", linguistic pluralism is a consequence of socio-political and economic reforms. Kazakhstan's society is becoming more open, the state is entering the world community, cultural, political, and economic ties between states are developing and strengthening. Foreign languages are in demand for society. Multilingual education is associated with the implementation of the parameters of the Bologna process, correlation and unification of curricula with European education standards.

In the annual Message \ The message of the Head of State Kassym-Jomart Tokayev to the people of Kazakhstan "The unity of the people and systemic reforms are a solid foundation for the prosperity of the country" the development of the Kazakh language determines the development of state policy. Kazakh is the language of office work, culture, science and education. The scope of 
application of the Kazakh language is expanding, there are no grounds to talk about its disadvantaged position. The official language is Kazakh. The official language is Russian. The study of the state language testifies to patriotism. The country benefits from the youth's proficiency in various languages, including Russian. [Official website of the President of the Republic of Kazakhstan, 2021]

Knowledge of Kazakh, Russian and English languages allows young people to adapt to world markets, science and new technologies, contributes to the formation of a mindset for cooperation when familiarizing with Kazakh, world, ethnic cultures. The new model of education involves teaching in three languages at the same time. Multiculturalism of Kazakhstan is a factor of social development.

In accordance with the State Program for the Development of Education and Science of the Republic of Kazakhstan for 2020 - 2025 (Resolution of the Government of the Republic of Kazakhstan dated December 27, 2019 No. 988), the purpose of the program is to increase the competitiveness of Kazakhstan's education and science, education and training of the individual on the basis of universal values, increasing the contribution of science to the socio-economic development of the country. Objectives of the program in accordance with the studied topic, the strengths of the educational process are multilingual education. [Official resource of the Prime Minister of the Republic of Kazakhstan, 2021]

\section{CONCLUSIONS}

Multicultural education in the Republic of Kazakhstan is a priority direction in the education system, a part of modern education that promotes the acquisition of knowledge about spiritual and cultural values, traditions of other peoples, which is a stage in the formation and development of a multicultural, tolerant person who respects his culture, the culture of other peoples; a stage of awareness and purposeful creation of value orientations, life principles and priorities of the younger generation. Kazakh is the state language, Russian is the language of interethnic communication and English is the language of successful integration into the global economy. The idea of the trinity is important, formulated by the head of state, a response to the challenge of time, a solution to the vital needs of society. The world is open to those who possess new knowledge through mastering the dominant languages. The state has started to implement the concept of multilingualism in education, strengthening the competitiveness of Kazakhstan. Multilingual education is elevated to the rank of state policy. Multilingualism is explained by changes in culture, education, politics, and economics.

Purposeful, systematic understanding of the phenomenon of multilingual education began relatively recently, except for the search for effective methods of teaching foreign languages. Indeed, the efforts of researchers have so far focused mainly on the problems of bilingual education (the study of the native language and a foreign one) as the most common form of multilingual learning. The processes associated with the development of a third language and, moreover, even more languages, are the least studied and have become the object of research only recently because of the plans of the European Commission to legalize trilingual education.

Trilingualism is assumed by the UNESCO concept, according to which it is assumed to study the native, regional or national and international language. The principle of multilingualism is defined by the European Union [Linde \& Petrova, 2018; Nenkov et al, 2017]. In 1995, the European Commission published an official report on education issues, defining the need for trilingualism of European citizens. For the first time, the idea of the trinity of languages was considered by N. Nazarbayev in 2004. In October 2006, at the XII session of the Assembly of People of Kazakhstan, the President noted the importance of learning three languages. In 2007 In his Address to the People of Kazakhstan "New Kazakhstan in a New World", N. Nazarbayev proposed to start the 
implementation of the project "Trinity of Languages", which indicates the need to study Kazakh - the state language, Russian - the language of interethnic communication and English as the language of successful integration into the global economy.

\section{REFERENCES:}

Linde, I., Petrova, M. (2018) The challenges of formalization and modeling of Higher Education Institutions in the 21st century. CBU International conference proceedings 2018: Innovations in Science and Education, 21.-23.03.2018, pp.303-308, https://doi.org/10.12955/cbup.v6.1173

Nenkov, N., Dyachenko, Yu., Petrova, M., Bondarenko, G., Pustovit, V. (2017). Intelligent and Cognitive Technologies in Education of International Economic Relations Students and Human Resource Development in Enterprises: Methodology in Language. European Journal of Sustainable Development, Publisher: European Center of Sustainable Development, ISSN 22395938 (print), ISSN 2239-6101(online), http://www.ecsdev.org/, Rome, Italy, Vol 6, No.4, 2017 , pp.353-360, https://doi.org/10.14207/ejsd.2017.v6n4p353

Official resource of the Prime Minister of the Republic of Kazakhstan. Retrieved October 26, 2021, from https://primeminister.kz/ru/gosprogrammy/gosudarstvennaya-programma-razvitiyaobrazovaniya-i-nauki-respubliki-kazahstan-na-2020-2025-gody-9114129

Official website of the President of the Republic of Kazakhstan. Retrieved October 26, 2021, from https://www.akorda.kz/ru/poslanie-glavy-gosudarstva-kasym-zhomarta-tokaeva-narodukazahstana-183048

Sagatov, A.S., Kusheeva, M.K. (2017). About the role of the Russian language in Kazakhstan // Materials of the IX International Student Scientific Conference "Student Scientific Forum". Retrieved October 26, 2021, from http://<ahref="https://scienceforum.ru/2017/article/2017038074"> https://scienceforum.ru/2017/ article/2017038074</a $>$

Site "Inform Buro". Retrieved October 26, 2021, from https://informburo.kz/novosti/dolya-kazaxovv-etniceskom-sostave-naseleniya-kazaxstana-sostavlyaet-pocti-70 